\title{
Petrography and stable isotope geochemistry of cretaceous sandstones, Orange Basin, South Africa
}

\author{
Solomon Adeniyi Adekola • Akinsehinwa Akinlua
}

Received: 3 October 2012/Accepted: 26 January 2013/Published online: 9 March 2013

(C) The Author(s) 2013. This article is published with open access at Springerlink.com

\begin{abstract}
Some siliciclastic rock samples of the Orange Basin were subjected to diagenetic and reservoir quality evaluation; 33 core and side wall core samples from 8 wells within the genetically related packages (systems tracts); lowstand systems tract, transgressive systems tract and highstand systems tract were collected for this study, to determine the prevailing conditions at deposition and post deposition of the sediments within the age bracket of Barremian to Campanian. The samples were subjected to petrographic and mineralogical analyses including bulk stable isotope analysis of oxygen and carbon. From the petrography of the samples, the basin shows complex diagenetic histories which include compaction, cementation/micritization, dissolution, overgrowth of quartz, and fracturing. The Eh-pH shows that the cements in the area of the basin under investigation were precipitated under weak acidic and slightly alkaline conditions. The $\delta^{18} \mathrm{O}$ isotope values of the samples range from -1.648 to $16.180 \%$ whilst $\delta^{13} \mathrm{C}$ isotope values range from -25.86 to $-6.95 \%$, which is indicative of terrestrial biomass contribution. The plot of $\delta^{18} \mathrm{O}$ versus $\delta^{13} \mathrm{C}$ shows that the sediments were deposited in shallow marine temperate
\end{abstract}

\section{S. A. Adekola · A. Akinlua}

Department of Earth Sciences, University of the Western Cape, PMB X17, Bellville, Cape Town 7535, South Africa

Present Address:

S. A. Adekola

Department of Geology, Obafemi Awolowo University,

Ile Ife, Nigeria

\section{A. Akinlua ( $\square)$}

Fossil Fuels and Environment Geochemistry Group,

Department of Chemistry, Obafemi Awolowo University,

Ile Ife, Nigeria

e-mail: aakinlua@oauife.edu.ng conditions with some Barremian and Aptian samples more marine. There is no significant variation of $\delta^{13} \mathrm{C}$ isotope values across the stratigraphic sequences, which could be an indication that the burial diagenesis does not have significant effect on geochemical pattern of the $\delta^{13} \mathrm{C}$ isotope in the sandstones but contribution from land-derived materials. The authigenic minerals precipitated blocked the grain interspaces and interlayers and with continued burial, compaction impeded the development of secondary porosity resulting in the poor reservoir quality. The origins of the cementing materials were both autochthonous and allochthonous.

Keywords Siliciclastic - Orange Basin - Authigenic minerals · Diagenesis - Stable isotopes - Reservoir quality

\section{Introduction}

The Orange Basin clearly defined syn-rift and drift phases of sedimentation (Broad et al. 2006). The earliest syn-rift sediments are fluvial and lacustrine in origin in some places with volcanics and volcanoclastics, which is overlain in some places by deltaic and shallow marine sediments. The drift succession is characterized by deep water argillaceous sediments, often with basin floor fan and associated sandy turbidites (Broad et al. 2006). Orange Basin in the south western margin of the Atlantic Ocean showed variable reservoir rock qualities (Macdonald et al. 2003). These cretaceous (Barremian-Santonian) clastic sediments marked by regional unconformities 6-15 At1 (Brown et al. 1996) have not been widely studied to ascertain the reasons for the variable reservoir qualities as reported by (Macdonald et al. 2003). The sequence comprises upward coarsening predominantly siliclastic, deltaic deposits of 
areally restricted red beds, marine sandstones and shales (Gerrard and Smith 1982). The lithology of this interval varies from north to south. In the north of the study area, shales rest on gas-bearing sandstones intercalated by basaltic lavas (Gerrard and Smith 1982). However, well A_C2 in our study area (Fig. 1) encountered mainly sandstones and minor conglomerates (Gerrard and Smith 1982). Between the deposition of the Aptian horizon (13 At1) and the Cenomanian/Turonian horizon (15 At1) sedimentation was more clay-rich than before and included coarsening upward silts to medium sandstones. Massive sandstones developed locally across the paleo outer shelf (Hirsch et al. 2010). This section of the basin is characterized by drifting and the resulting graben filled with predominantly siliciclastic continental and lacustrine rocks, with variable thicknesses of volcanic rocks (Brown et al. 1996). The Orange Basin features the highest post rift sediment accumulation at the South Western African margin (Dingle and Hendy 1984). The basin is filled with post rift cretaceous siliciclastic rocks ranging in age from late Hauterivian drift onset to tertiary (Brown et al. 1996). The opening of the South Atlantic is recorded by five main tectonic-stratigraphic sequences at the South African continental margin which are: the basin and range or pre-rift mega-sequence, the syn-rift I and II mega-sequence, the transitional and thermal sag mega-sequence (Fig. 2) (Maslanyi et al. 1992; Light et al. 1993). In the basin, a total of 34 wells have been drilled with only one oil discovery and a number of gas discoveries to date (PASA 2003). This is a pointer to the fact that the basin is under explored.

Data about the events at deposition and post deposition of the sediments are scarce, which the present study will attempt to investigate. The investigation will involve looking at the mode of deposition of sediment on a regional scale within the genetically related packages and ages and possibly establishes its diagenetic sources. Diagenetic evolution of siliciclastic deposit is complex and controlled by several inter-related factors which include: changes in detrital composition in particular extrabasinal and intrabasinal grains (Garzanti 1991; Zuffa et al. 1995; Ketzer et al. 2002), pore water chemistry (Mckay et al. 1995; Morad et al. 2000), residence time of sediment under certain geochemical conditions (Wilkinson 1989; Taylor et al. 1995; Morad et al. 2000). All these complexities have been unravelled by sequence stratigraphic approach because variations in these factors are marked by sequence stratigraphic surfaces (such as parasequence boundaries, transgressive surface and maximum flooding surfaces (El-ghali et al. 2009). The sequence stratigraphic tool has been widely used to correlate genetically related sedimentary successions bounded at top and base by unconformities or their strata patterns interpreted in response to interaction of

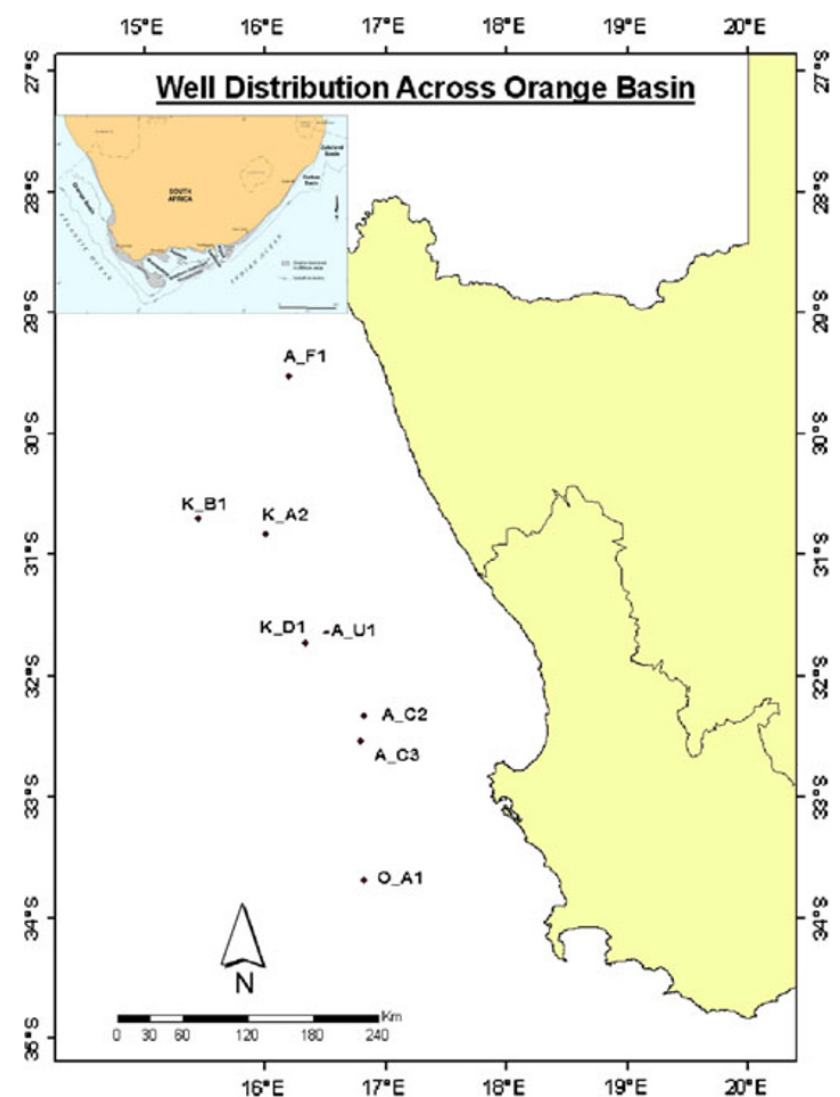

Fig. 1 Map of the offshore wells distribution in the Orange Basin, insert is the map of South Africa showing the position of the basin (modified from Broad 2004)

eustatic change of sea level, compaction, sediment supply and tectonic subsidence (Van Wagoner et al. 1990).

In the present study, the distribution of diagenetic alterations and their effects on the reservoir rock quality of the sandstones within the stratigraphic sequences of the Orange Basin was investigated.

\section{Geologic setting of Orange Basin}

The Orange Basin offshore Southwest Africa is located within the passive continental margin of the South Atlantic between $31^{\circ}$ and $33.3^{\circ}$ latitude (Fig. 1). It was formed as a result of the break-up of South America and Africa in the Late Jurassic, which was followed by seafloor spreading and the opening of the South Atlantic Ocean in the Early Cretaceous around $136 \mathrm{Ma}$ (Brown et al. 1996; Reeves and De Wit 2000; Macdonald et al. 2003). It was formed within divergent plate boundary settings in response to the lithologic extension related to the break-up.

McMillan (2003) said cretaceous marine sediments of the west coast of South Africa were deposited in a series of offshore basin since about $127 \mathrm{Ma}$ ago, with sedimentation controlled by the tectonic uplift or subsidence of continental margin. The major sediment deposition in the 

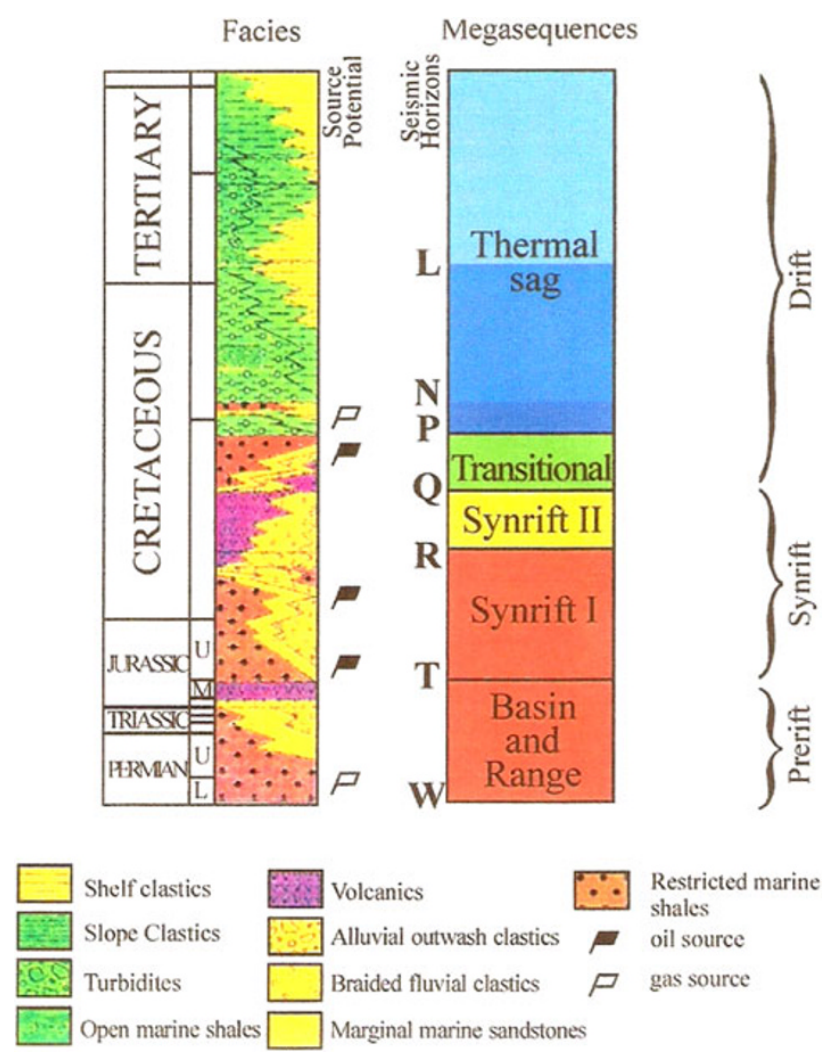

Fig. 2 Stratigraphy and seismic horizons of the South-west African offshore (Orange Basin) (modified from Light et al. 1993)

offshore Orange Basin was during late cretaceous to early tertiary (Dingle and Hendy 1984; Brown et al. 1990; Rust and Summerfield 1990). Rust and Summerfield (1990) put the volume of sediment deposited in the basin to approximately $2.8 \times 10^{6} \mathrm{~km}^{3}$. The erosional surfaces or cycles that developed during the cretaceous were separated by tectonic episodes (King 1967, 1976, 1983). During the period from the end of cretaceous to the pleistocene, four hiatuses in sedimentation have been identified from seismic and drilling surveys conducted in the sedimentary fill of the offshore basin (Siesser and Dingle 1981; Aizawa et al. 2000). (Emery and Uchupi 1984) recorded that the Orange Basin has sediment accumulation up to approximately $7 \mathrm{~km}$. At the end of Cenomanian Atlantic fully opened (Brown et al. 1996; SOEKOR 1994a, b), this really helped in creating accommodation space for the sediments to be deposited. There was deposition of at least 30 third-order post-rift sequences during the cretaceous (Fig. 3) (Brown et al. 1996; Broad et al. 2006).

Lithostratigraphy and sequence stratigraphy of the wells

Lithostratigraphic interpretation of the studied wells was based on the relative percentage of sand and shale and the presence of shale intercalation. The major lithostratigraphic units encountered are between 13 and 22 At1 (Fig. 4). The section consists of predominantly sand with shale intercalations. The predominantly sandy nature of the deposit may suggest deposition in high energy depositional environments, probably during the progradational phase of the basin. Sediment input to the basin was from right to left (Fig. 4). Seven depositional sequences bounded by eight sequence boundaries were delineated in this study. Each of these sequences is produced by a cycle of sea level fluctuation and has been designated as sequence I, II, III, IV, V, VI and VII between 13 and 22 At1 in the study area. The sand bodies show hybrid unit consisting of a built up multiserrate cylinder-shaped, upward fining, as well as upward coarsening units, probably of subaqueous channel and barrier bar deposits in shallow water setting. Sequences I to IV show predominantly base which are shaly, indicative of deposition in low energy depositional environment. Sequences V to VII show sand bodies which grade vertically upward into transitional shallow marine sand as observed in wells K_A2, K_B1 and A_F1.

\section{Materials and methods}

This study was carried out using digital wireline logs, sandstone sidewall core and core samples obtained from Petroleum Agency South Africa (PASA). All the samples are reservoir rocks. The wireline logs were interpreted and broken to stratigraphic sequences. Core and sidewall core samples were collected within systems tracts; lowstand systems tracts (LST), transgressive systems tracts (TST) and highstand systems tracts (HST), to investigate the effect of diagenetic alterations within the framework. 33 sandstone samples were collected from 8 wells (Table 1) at different systems tracts and ages in the transitional and drift sessions of the basin (Figs. 3, 4) (Barremian-Campanian). Thin sections were prepared from core samples and subjected to petrographic analysis, X-ray diffraction (XRD), scanning electron microscopy/energy dispersive spectrometry (SEM/EDS) and stable isotope analysis of the samples were also carried out to reveal the conditions at deposition and post deposition in the basin.

The thin sections were prepared by laying samples set in open sample trays with clean glass slides. Sample numbers were marked on the glass slide with diamond scriber. Sample number checked against the marked number on the glass slides to ensure the sample identity is correct. The samples were ground to a flat surface using only diamond abrasive with distilled water. Sample grinding was done by hand on a flat plate for the core samples. Samples that required stabilization (the side wall core samples) prior to grinding, were stabilized. Epoxy stabilization was done in a plastic using 


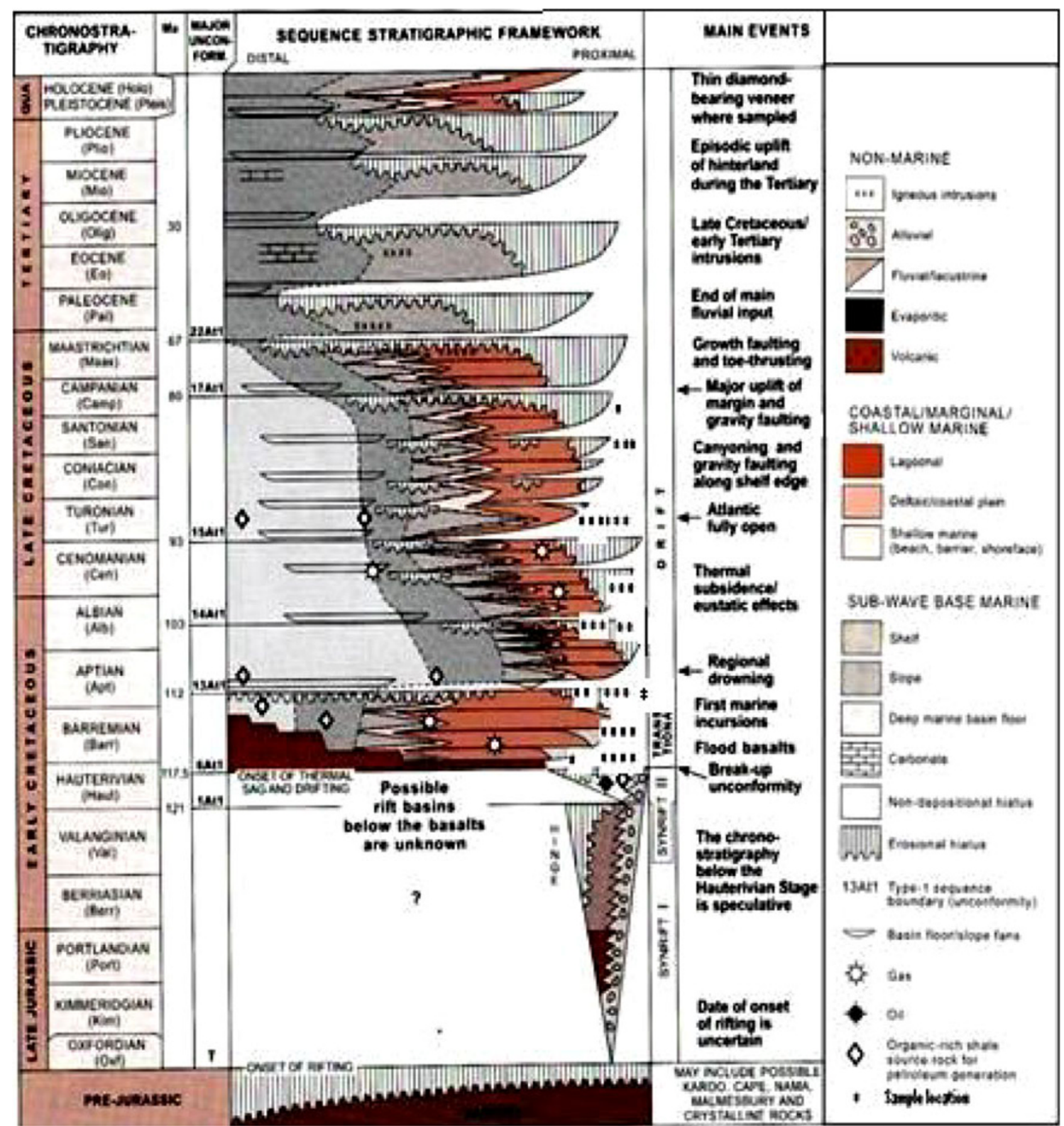

Fig. 3 Generalised chronostratigraphy and sequence stratigraphy of Orange Basin offshore Mesozoic basin showing sample locations, based on results of sequence stratigraphic studies (modified after Broad et al. 2006)

Epon 815-diethylene-triamine. The glass slide tray was ensured to be next to the samples. The sample was allowed to cure at room temperature. Final grinding of the surface to be mounted on the glass slide was done using 400-mesh diamond plate. Lapping was done using glass impregnated plate. $10 \times$-power magnification microscopes were used in observing the progress of the grinding. The prepared slides were analyzed using petrographic microscope.

The SEM/EDS analyses involve each samples coated with gold palladium for about $30 \mathrm{~min}$. This was done to make the samples conductive. The coated sample was put on a palette-like stand which was placed under an electron beam. SEM analysis was performed using a LEO Stereoscan 440 which is a high vacuum microscope. It has a stereo workstation attached to the instrument which enables the image taken by the electron microscope to be viewed on the computer. There is an allowance for magnification adjustment of the view to have a better and accurate view of the image. Freezing the view enables the image to be taken and snapshot of the desired image (s) can be taken for analysis. A dispersive X-ray spectrometer (EDS) coupled with a computer-based multichannel analyzer (MCA) was used for this analysis. The SEM and the EDS were done simultaneously. A conventional Be 


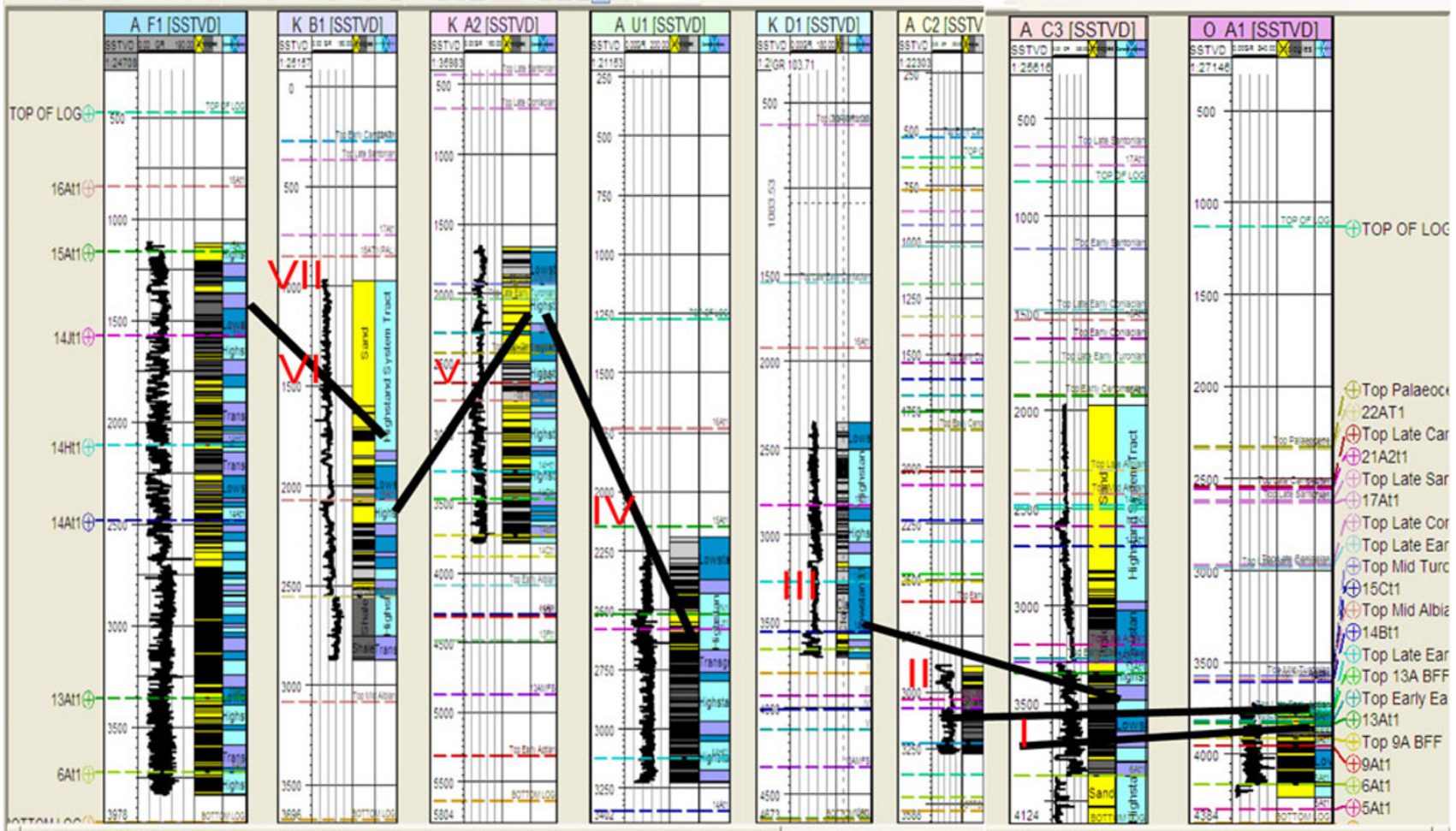

Fig. 4 Lithostratigraphic and sequences correlation of the investigated well in Orange Basin, South western Atlantic

Table 1 Distribution of sandstone samples in according to the different wells, ages, systems tracts and cycle of depositions

\begin{tabular}{|c|c|c|c|c|c|c|c|c|c|c|c|}
\hline \multirow[t]{2}{*}{ System } & \multirow[t]{2}{*}{ Age (Ma) } & \multicolumn{8}{|c|}{ Number of samples from different wells } & \multirow[t]{2}{*}{ Sequ } & \multirow[t]{2}{*}{ Cycle } \\
\hline & & K_B1 & A_F1 & A_U1 & K_D1 & O_A1 & A_C2 & A_C3 & K_A2 & & \\
\hline \multirow[t]{10}{*}{ Upper Cretaceous } & Campanian (70.6-83.5) & 1 & & & & & & & & HST & VII \\
\hline & Santonian (83.5-85.8) & 3 & & & & & & & & LST & VI \\
\hline & Turonian (89.3-93.5) & & 3 & & & & & & & HST & $\mathrm{V}$ \\
\hline & & & & & & & & & 3 & TST & \\
\hline & & & & & & & & & & LST & \\
\hline & Cenomanian (93.5-99.6) & & & & & & & & & HST & IV \\
\hline & & & & 3 & & & & & & TST & \\
\hline & & & & & & & & & & LST & \\
\hline & Albian (99.6-112.0) & & & & 1 & & & & 1 & HST & III \\
\hline & & & & & 1 & & & 1 & 1 & LST & \\
\hline \multirow[t]{6}{*}{ Lower Cretaceous } & Aptian (112.0-125.0) & & & & 2 & & & & & HST & II \\
\hline & & & & & & & 2 & 2 & & TST & \\
\hline & & & & & & & & & & LST & \\
\hline & Barremian (130.0-125.0) & & & & & 4 & & & & HST & I \\
\hline & & & & & & 1 & & & & TST & \\
\hline & & & & & & 3 & & 1 & & LST & \\
\hline
\end{tabular}

window, $\mathrm{Si}(\mathrm{Li})$ detector with a 1,024 channel MCA set to $10 \mathrm{eV}$ per channel was employed. Picoammeter was attached to measure beam and or specimen current. Samples were metallographically polished starting with 6-3 micron and ending with 1 micron grit with diamond paste to make them conductive. The detrital and authigenic minerals identification in the samples was carried out using $\mathrm{X}$-ray diffraction.

Oxygen and carbon isotopes data were obtained from bulk-rock samples. Roasting of the samples were done for $48 \mathrm{~h}$ at $50{ }^{\circ} \mathrm{C}$ in high vacuum glass followed by dissolution in orthophosphoric acid at $90{ }^{\circ} \mathrm{C}$ under high vacuum for 
$12 \mathrm{~h}$. The evolving $\mathrm{CO}_{2}$ was cryogenetically separated from other gases and measured with a Finnigan Delta $\mathrm{S}$ mass spectrometer. The isotopic results were reported in the usual $\delta$ notation versus the sea mean ocean water (SMOW) for oxygen and Vienna PeeDee Belemnite (PDB) standards for carbon.

\section{Results}

Results of petrographic analysis

The results of the thin section showed that the major detrital minerals present in different stratigraphic sequences and ages of the area under investigation are quartz, rock fragments, mica and feldspars. Accessory minerals observed include glauconite, hematite and pyrite. Authigenic minerals observed include chlorite and montmorillonite.

Quartz, rock fragments, mica and feldspars are the major detrital minerals present in the LST samples which are of Barremian, Albian and Santonian ages (Fig. 5a-d). Chlorite is the most abundant authigenic mineral in these samples (Fig. 5e). Some accessory minerals like pyrite and hematites are also present (Fig. 5e).

Quartz and mica as the major detrital minerals present in the TST samples which are of Barremian and Aptian ages (Fig. 6a-d). The dominant authigenic mineral present in this systems tract is chlorite. Accessory minerals like hematite, pyrite and glauconite are also present in the TST samples (Fig. 6a, c, e).

The HST samples which are of Aptian, Turonian and Campanian ages show the presence of abundance of quartz with chlorite as the major authigenic mineral, and trace amount of montmorillonite was also observed (Fig. 7a-d). Hematite is the dominant accessory mineral present in the HST samples (Fig. 7e).

Results of stable isotope geochemical analysis

Carbon and oxygen stable isotope data are presented in the $\delta$ notation relative to the Vienna PeeDee Belemite (PBB) and standard mean ocean water (SMOW), respectively (Table 2). The variations in $\delta^{13} \mathrm{C}$ and $\delta^{18} \mathrm{O}$ values across the study area and different geologic ages are presented in Fig. 8. Within the LST, the values of $\delta^{13} \mathrm{C}$ and $\delta^{18} \mathrm{O}$ increase with depth in all the wells except in well K_D1 (Table 2). Samples in the TST also show increase of $\delta^{13} \mathrm{C}$ and $\delta^{18} \mathrm{O}$ values with depth except in well A_C2. In the HST, the values of $\delta^{13} \mathrm{C}$ increase with depth except in well K_D1. The $\delta^{18} \mathrm{O}$ values increase with depth in all the wells except in wells K_D1 and K_A2 (Table 2).

\section{Discussion}

Petrography of sandstones within the stratigraphic settings

The detrital, authigenic and accessory minerals which are the most abundant in the LST blocked the available pore spaces thereby impairing the reservoir quality of the sandstones in this systems tract. The samples also show evidence of fracturing, which would have enhanced permeability of the sandstones (Fig. 5a, c, d) but the fractures are not connected. The Santonian sample in LST exhibits fracturing (Fig. 5b) which has healed up, thus it would make fluid flow almost impossible. The major cementing material in this systems tract is dense micritic calcite.

It is inferred that the alteration of the mica must have been responsible for the formation of the authigenic chlorite (De Ros 1998). The framboidal pyrite present in the TST samples (Fig. 6c) is squeezed within the pores of the sample matrix. Figure $6 \mathrm{c}$ reveals that the sandstone is composed mainly of quartz grains embedded in coarse crystalline calcite cement. The TST samples are composed of quartz, feldspar and green glauconite grains embedded in microsparry calcite cement (Fig. 6d). The major cementing material in the LST is dense micritic calcite.

The petrography of the HST samples revealed that calcite is the major cementing material in the Turonian age samples (Fig. 7a), while the cementing material present in the Campanian age samples is dense micritic calcite found filling microcavities in severely altered rock (Fig. 7c). The abundance of hematite increases from LST to TST and in turn to HST.

Diagenetic alteration processes and reservoir environmental evolution

The combination of stable isotope data with petrographic data of the rock samples can be used to determine the geochemical environment of formation of authigenic minerals and thereby elucidate diagenetic mechanisms (Shikazono and Utada 1997). The petrographic data show that the Orange Basin has a complex diagenetic history (Fig. 8). These diagenetic processes include compaction, cementation/micritization, dissolution, silicification, and fracturing.

Post-depositional events across the stratigraphic settings

\section{Compaction}

The petrographic data of the HST samples revealed evidence of tight packing and point grain contacts, consequently reduced primary depositional porosity before 

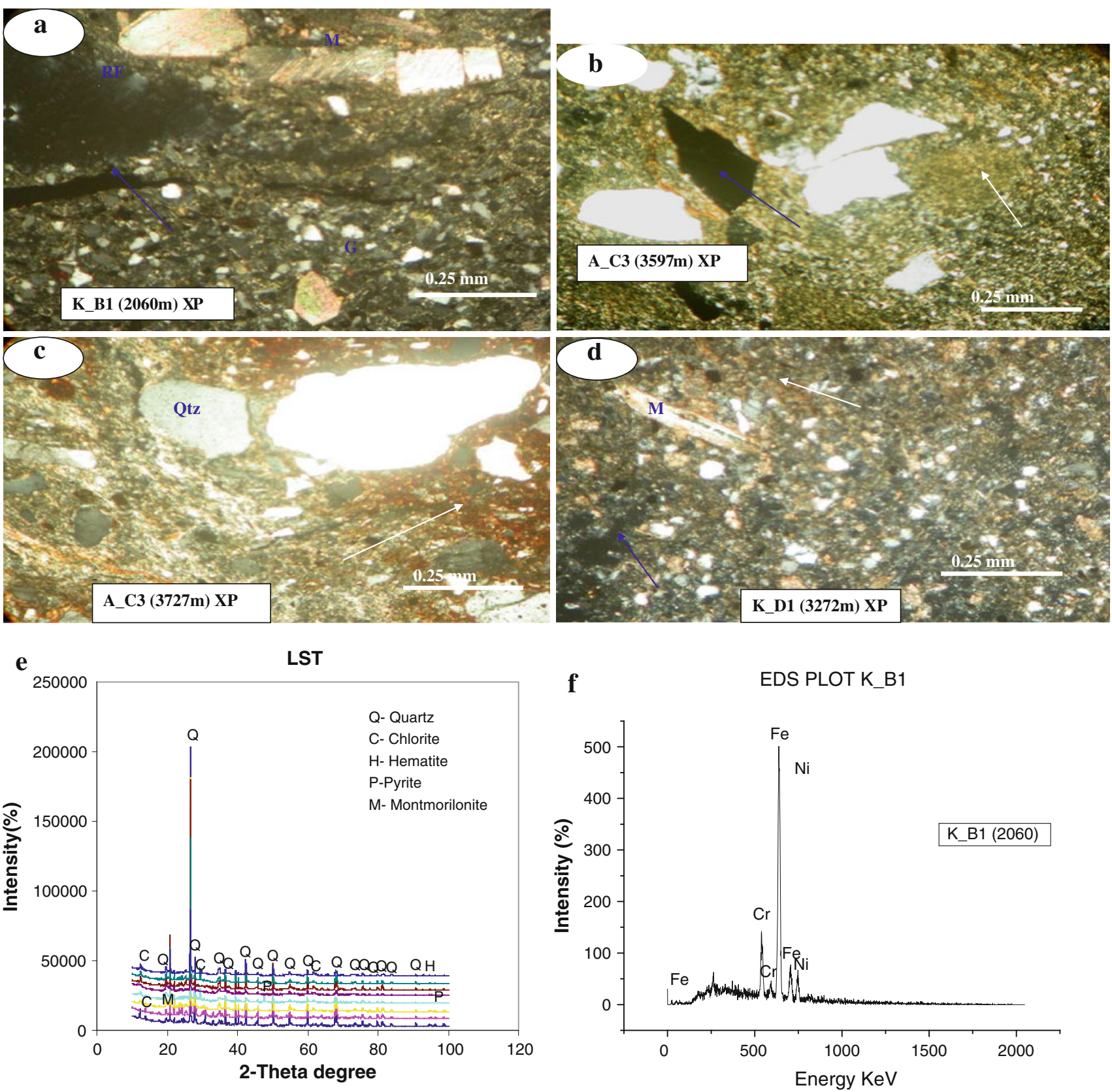

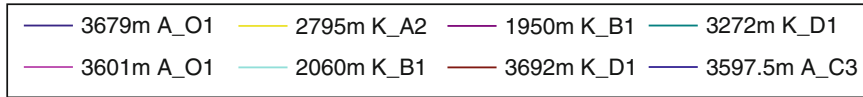

Fig. 5 Optical photomicrographs representative samples within LST showing: a microcrystalline micritic cement coating around fractured (blue arrow) detrital grains in Santonian age. b Dense micritic calcite cement completely covering the detrital grains in which the fractured is healed up in Santonian age. c Dense micritic calcite cement completely filling up the pore spaces of the fractured (blue arrow) detrital grain in Barremian age. d Dense micritic calcite cement

cementation began (Fig. 7a). As reported by Morad et al. (2000), eodiagenesis takes place at a depth less than $2 \mathrm{~km}$ and temperature less than $70{ }^{\circ} \mathrm{C}$. Samples from well K_A2 support this postulation (Fig. 7a). There was an increase in completely filling up the pore spaces of the fractured (blue arrow) detrital grains with mica (m) flattened in Albian age. e The XRD results of all the samples within LST showing abundance of quartz $(Q)$ some chlorite $(C)$, montmorillonite $(M)$, pyrite $(P)$ and hematite $(H)$. f The EDS result showing high intensity of iron $(\mathrm{Fe})$ which completely replaced silicon $(\mathrm{Si})$

the rate of sedimentation near the mouth of the Orange River during the late cretaceous (Rust and Summerfield 1990), which led to breaching at this time in the south western Africa margin (Gilchrist et al. 1994). This could have 

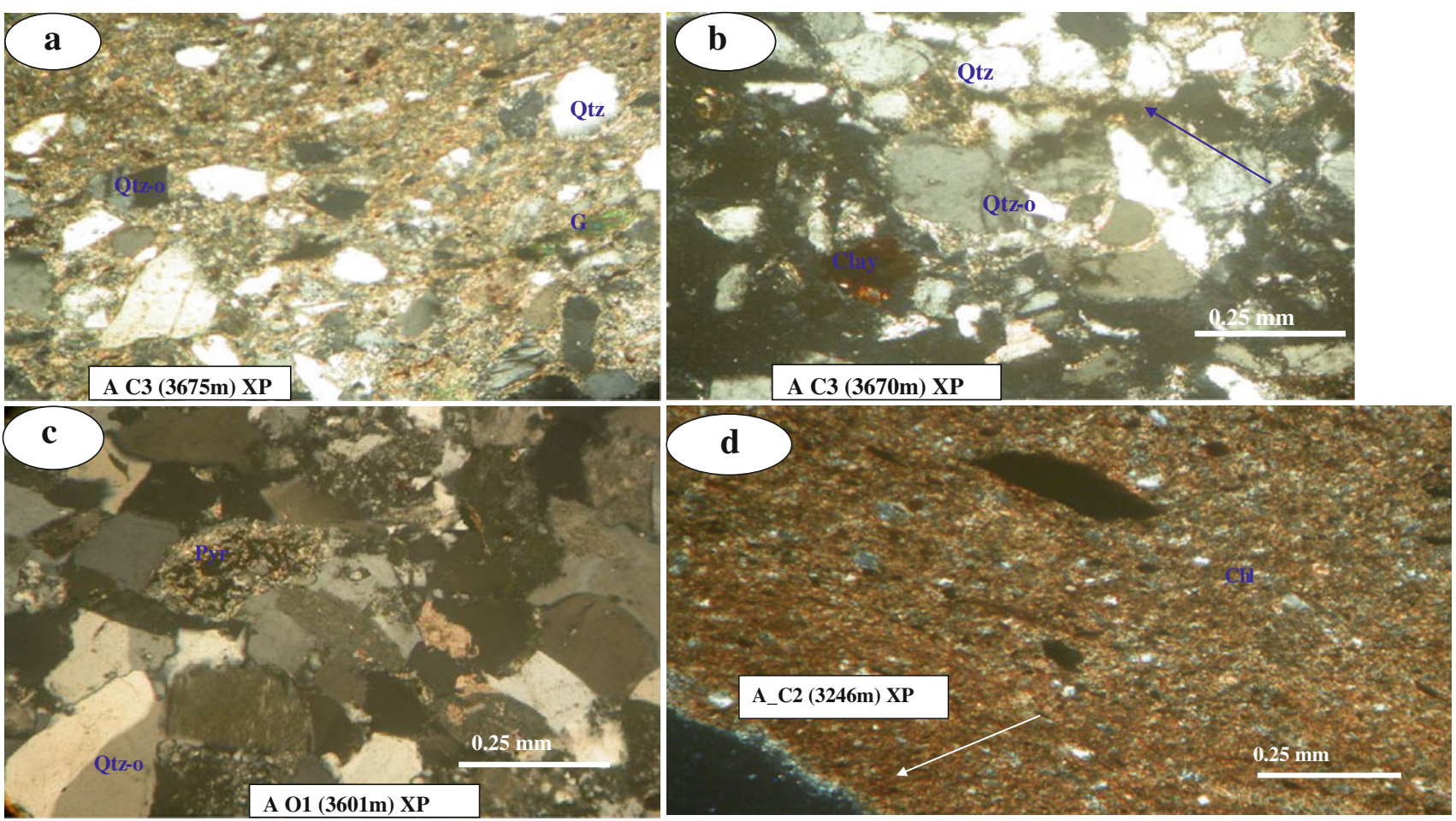

TST

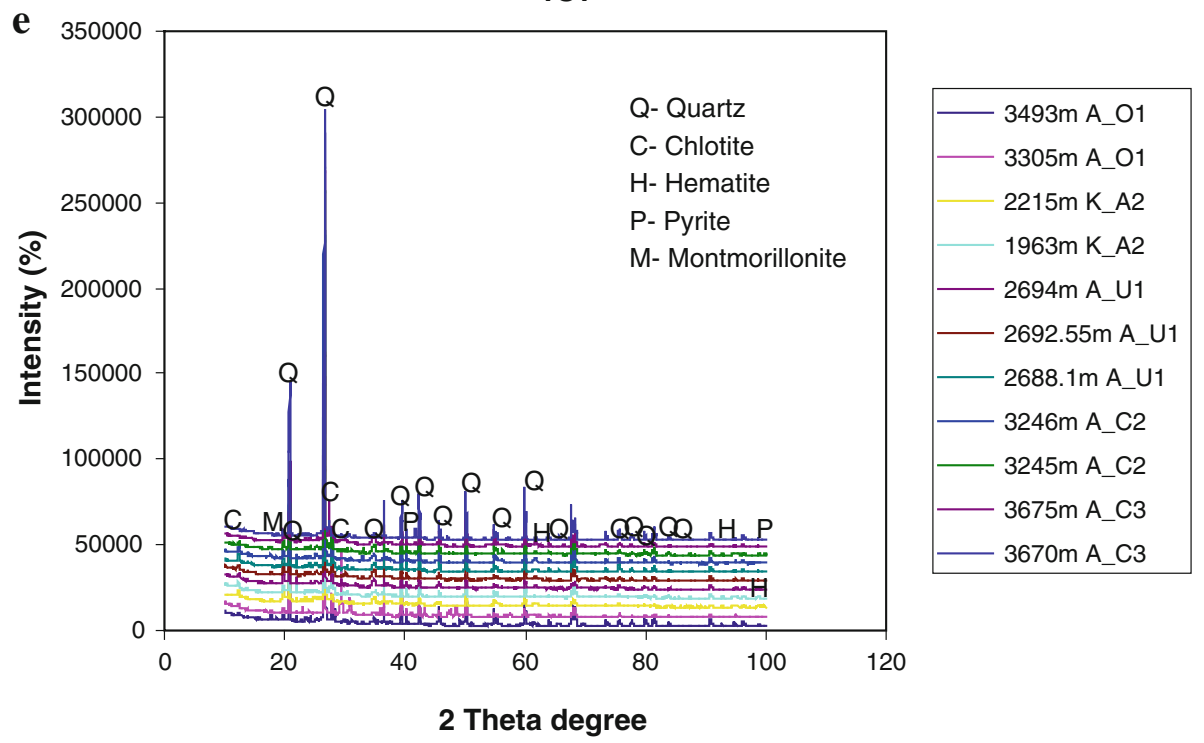

Fig. 6 Optical photomicrograph of results of representative sample within TST showing: a dense micritic calcite cement partially filling up the pore spaces of the detrital grain in Aptian age. b Coarse crystalline calcite cement filling open pore of the detrital grains in Aptian age. c Coarse crystalline calcite cement filling open pore with some pyrite $(\mathrm{P})$, overgrowth of quartz (Qtz-o) in Barremian age

imposed severe pressure on the sediments and hence enhancing the constituent particles to be tightly packed. Other evidence of compaction is the flattening of mica and rock fragment in K_B1 sample in the LST even distal to the mouth of Orange River (Figs. 4, 5a, b) and HST samples (Fig. 7d). d Dense micritic calcite cement completely filling up the pore spaces of the detrital grains with mica (m) completely altered as specs in chlorite (Chl) rim in Aptian age. e The XRD result of all the samples within LST showing abundance of quartz $(Q)$ some chlorite $(C)$, montmorillonite $(M)$, pyrite $(P)$ and hematite $(H)$

\section{Cementation/micitization}

The difference in the nature fabric of the cements of the sandstones is suggesting that precipitation of the cements occur in different diagenetic environments, from marine 

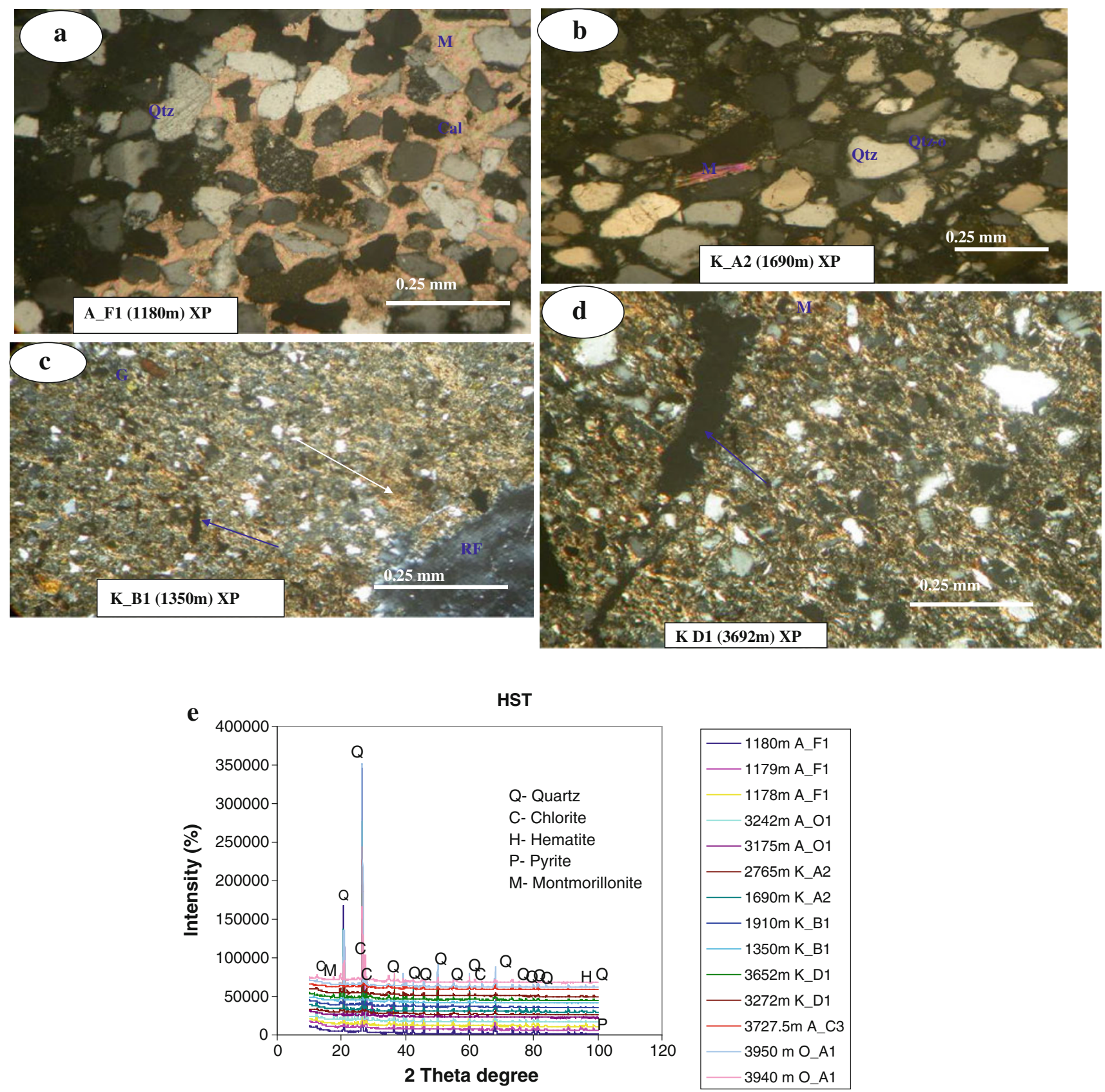

Fig. 7 Optical photomicrograph of results of representative sample within HST showing: a the sandstone composed of mainly quartz $(\mathrm{Qtz})$ grains embedded in poikilitopic calcite $(\mathrm{Cal})$ cement in Turonian age. b Coarse crystalline calcite cement filling open pore of the detrital grains with mica $(\mathrm{m})$ flattened and overgrowth of quartz (Qtz-o) in Turonian age. c Dense micritic calcite cement completely

through meteoric. The cement observed in the LST sandstone samples is micritic calcite, completely filling the pores, which is an evidence of marine diagenesis (Elghali et al. 2009). The first marine incursion to the basin was during Barremian (Broad et al. 2006) in which the oldest sample in this study was deposited. The cementing conditions within the TST and HST are not similar; this filling up the pore spaces of the fractured (blue arrow) detrital grain with glauconite $(G)$ and rock fragments $(R F)$ in Campanian age. d Dense micritic calcite cement completely filling up the pore spaces detrital grains in Aptian age. e The XRD result of all the samples within HST showing abundance of quartz $(Q)$ some chlorite $(C)$, montmorillonite $(M)$, and hematite $(\mathrm{H})$

is suggesting different precipitation conditions within these packages. The cement type range from dense micritic calcite to grains embedded in poikilitopic calcite cement and also chlorite cement completely filling the pore spaces in TST sample of Aptian age (Fig. 6d). The cementation process really reduced the primary porosity because the pore spaces are severely blocked thereby 
Table 2 The results of stable isotope of oxygen and carbon with the pore water analysis results of different samples within the well according to stratigraphic sequence and ages

\begin{tabular}{|c|c|c|c|c|c|c|c|c|}
\hline $\begin{array}{l}\text { Well } \\
\text { name }\end{array}$ & $\begin{array}{l}\text { Depth } \\
(\mathrm{m})\end{array}$ & Age & Sequence & $\begin{array}{l}\text { Normalized U } \delta 180 \text { versus } \\
\text { VSMOW }\end{array}$ & $\begin{array}{l}\text { Normalized U } \delta 13 \mathrm{C} \text { versus } \\
\text { VPDB }\end{array}$ & $\mathrm{pH}$ & $\begin{array}{l}\mathrm{Ec} \\
(\mathrm{mS})\end{array}$ & $\begin{array}{l}\text { Eh } \\
(\mathrm{V})\end{array}$ \\
\hline K_B1 & 1,350 & Campanian & HST & 4.026 & -21.963 & nd & nd & nd \\
\hline K_B1 & 1,910 & Santonian & LST & 3.91 & -25.244 & 7.2 & 0.42 & 0.15 \\
\hline K_B1 & 1,950 & Santonian & LST & 10.054 & -12.512 & 7.6 & 0.62 & 0.16 \\
\hline K_B1 & 2,060 & Santonian & LST & 6.883 & -20.569 & nd & nd & nd \\
\hline A_F1 & 1,178 & Turonian & HST & -0.267 & -24.847 & 6.79 & 1.36 & 0.19 \\
\hline A_F1 & 1,179 & Turonian & HST & 0.482 & -24.841 & nd & nd & nd \\
\hline A_F1 & 1,180 & Turonian & HST & 16.18 & -21.307 & nd & nd & nd \\
\hline K_A2 & 1,690 & Turonian & TST & 7.376 & -23.224 & 7.8 & 0.56 & 0.17 \\
\hline K_A2 & 1,963 & Turonian & TST & 1.919 & -27.009 & nd & nd & nd \\
\hline K_A2 & 2,215 & Turonian & TST & 2.961 & -24.142 & 7.62 & 0.61 & 0.13 \\
\hline A_U1 & 2,688 & Cenomanian & TST & 2.345 & -23.839 & 8.15 & 0.44 & 0.18 \\
\hline A_U1 & 2,694 & Cenomanian & TST & 0.924 & -23.239 & nd & nd & nd \\
\hline A_U1 & 2,697 & Cenomanian & TST & 3.969 & -20.657 & nd & nd & nd \\
\hline K_A2 & 2,765 & Albian & HST & 2.099 & -25.667 & nd & nd & nd \\
\hline K_A2 & 2,795 & Albian & LST & 1.634 & -25.057 & nd & nd & nd \\
\hline K_D1 & 3,174 & Albian & HST & 3.92 & -22.064 & nd & nd & nd \\
\hline K_D1 & 3,272 & Albian & LST & 7.155 & -14.954 & nd & nd & nd \\
\hline A_C3 & 3,597 & Albian & LST & -1.648 & -23.203 & nd & nd & nd \\
\hline K_D $1^{a}$ & 3,652 & Aptian & HST & 4.956 & -23.018 & nd & nd & nd \\
\hline K_D1 & 3,692 & Aptian & HST & 2.227 & -24.381 & 8 & 0.52 & 0.14 \\
\hline A_C2 & 3,245 & Aptian & TST & -1.574 & -22.089 & 5.72 & 0.63 & 0.13 \\
\hline A_C2 & 3,246 & Aptian & TST & -1.169 & -22.104 & nd & nd & nd \\
\hline A_C3 & 3,670 & Aptian & TST & 3.705 & -23.149 & nd & nd & nd \\
\hline A_C3 & 3,675 & Aptian & TST & 1.567 & -24.502 & nd & nd & nd \\
\hline O_A1 & 3,175 & Barremian & HST & 7.356 & -9.75 & 6.7 & 0.54 & 0.14 \\
\hline O_A1 & 3,242 & Barremian & HST & 13.134 & -6.954 & nd & nd & nd \\
\hline O_A1 & 3,305 & Barremian & HST & 9.628 & -7.82 & 8.6 & 0.46 & 0.17 \\
\hline O_A1 & 3,493 & Barremian & HST & 2.233 & -19.935 & nd & nd & nd \\
\hline O_A1 & 3,601 & Barremian & TST & -0.162 & -27.862 & nd & nd & nd \\
\hline O_A1 & 3,679 & Barremian & LST & 0.685 & -27.407 & nd & nd & nd \\
\hline O_A1 & 3,862 & Barremian & LST & -2.644 & -22.834 & nd & nd & nd \\
\hline O_A1 & 3,874 & Barremian & LST & -1.132 & -22.636 & 7.2 & 0.43 & 0.19 \\
\hline A_C3 & 3,727 & Barremian & LST & -1.712 & -25.904 & 6.26 & 1.12 & 0.18 \\
\hline
\end{tabular}

${ }^{a}$ Moved to join Aptian in this new table. Formally sandwiched within Albian in old table

contributing to the poor quality of the reservoir rocks in these wells.

\section{Dissolution}

The LST samples have $\mathrm{pH}$ values that indicate weak acidic and slightly alkaline conditions (Table 2). The results of pore water analysis also show that the $\mathrm{pH}$ values of TST and HST samples indicate weak acidic to slightly alkaline conditions (Table 2). This should ordinarily aids leaching and generation of secondary porosity. This is not so in the wells studied because the pore spaces that could have been created through leaching are completely filled up by the process of cementation in all the stratigraphic sequences. The above conditions could be responsible for the authigenic minerals and cementing materials found across the stratigraphic sequences. Chlorite and montmorrilonite have been reported to be precipitated under weak acidic to alkaline conditions (Krumbein and Garrels 1952; Shikazono and Utada 1997) this is congruent with the results of this study because both minerals were identified in the rock samples investigated in this study. The micritc calcite cement has been also reported to be formed under these conditions. The authigenic kaolinite that is formed under 


\begin{tabular}{|l|l|l|}
\hline Diagenetic minerals & Eodiagenesis & Mesodiagenesis \\
${ } }$ & & \\
Chlorite & & \\
Montmorillonite & & \\
Glauconite & & \\
Quartz overgrowths & & \\
Hematite & & \\
Pyrite & & \\
Micritic calcite & & \\
TST & & \\
Chlorite & & \\
Montmorillonite & & \\
Glauconite & & \\
Quartz overgrowths & & \\
Hematite & & \\
Pyrite & & \\
Poikilitopic calcite & & \\
HST & & \\
Chlorite & & \\
Montmorillonite & & \\
Glauconite & & \\
Quartz overgrowths & & \\
Hematite & & \\
Pyrite & & \\
Poikilitopic calcite & & \\
\hline
\end{tabular}

Fig. 8 Paragenetic sequence of the diagenetic alteration within the stratigraphic settings of Orange Basin sandstones using XRD and thin section results. The boundary between eodigenesis is $<2 \mathrm{~km}$ and mesodiagenesis is $>2 \mathrm{~km}$ according to Morad et al. (2000)

strong acidic condition was not identified in any of the samples investigated.

\section{Quartz growth}

Well K_D1 samples (Fig. 7d) within the HST shows evidence of silicification which affect the whole skeletal grains in the samples. This is also observed in wells A_C3 and $\mathrm{K} \_\mathrm{B} 1$ samples in the LST and HST, respectively (Figs. 6c, 7c). Generally, silica occurs in form of chert and microcrystalline quartz. There is also an evidence of growth of quartz forming quartz overgrowth within the TST and HST settings (Figs 6b, 7b) of Aptian and Turonian ages, respectively.

\section{Fracturing}

The petrography of sandstone samples within LST reveals severe fracturing (Fig. 5a-d). In some cases, the fractures are healed up by new materials (Fig. 5b), in other cases the fractures are still preserved (Fig. 5a, d). It was observed in the TST and HST samples that fractures are covered or filled up with secondary calcite cements (Figs. 6a-d, 7a-d). Fracturing can enhance reservoir quality because when connected it improves permeability and transmissivity. In the stratigraphic sequences under investigation, the secondary mineral deposition severely impaired the reservoir quality of the sandstones, by covering every available space resulting in the poor quality of the reservoir rocks (Fig. 5a-d).

Geochemical events within the sandstones

The changes in climate have significant effects on the south western Africa margin during the Mesozoic and Cenozoic (Parrish et al. 1982; Ward et al. 1983; Tyson 1986). A scatter diagram of $\delta^{13} \mathrm{C}$ against $\delta^{18} \mathrm{O}$ (Fig. 9) of sandstone samples within different stratigraphic settings and ages of the Orange Basin show that the cements were precipitated under temperate and shallow marine conditions (Milliman and Muller 1977; James and Choquette 1983; Adabi and Rao 1991; Rao and Nelson 1992; Allan and Wiggins 1993; Mahboubi et al. 2002). The cement of LST samples using oxygen and carbon stable isotope data falls within temperate and shallow marine fields (Fig. 9) (Scholle 1978; Bellanca et al. 2005). Some Barremian and Aptian samples and one Turonian sample were deposited in shallow marine conditions (Fig. 9). The first marine input to the basin happened between Late Hauterivian and Early Aptian (112-117.5 Ma) just after the break-up unconformity at $117.5 \mathrm{Ma}$ (SOEKOR 1994a, b; Brown et al. 1996). Sample K_B1 at depth $2,060 \mathrm{~m}$ of Turonian age shows the presence of glauconite which is diagnostic of continental shelf marine environment (Odin and Matter 1981). Rust and Summerfield (1990) reported increase in the rate of sedimentation near the mouth of Orange River in the late cretaceous. This was substantiated by Gilchrist et al. (1994) by suggesting that breaching may have occurred at this time in the south western African margin. Some of the samples were probably deposited at this time as a result of filling the gap that was created.

Well K_D1 samples show depletion in oxygen down the depth (Table 2). This depletion may be as a result of recrystallization at higher temperature associated with greater burial depth sediment-hydrothermal fluid interaction and mixing with meteoric water (Bellanca et al. 2005). $50 \%$ of the samples in LST falls within the range of mixture of detrital quartz which is put at $6.4-20 \%$ for $\delta^{18} \mathrm{O}$ (Table 2) (Garlick and Epstein 1967; Savin and Epstein 1970; Clayton et al. 1972; Eslinger et al. 1973; Blatt 1986; Graham et al. 1996).

The moderately negative carbon isotope composition of $50 \%$ of the samples indicates a normal marine signature that was influenced by sedimentary organic matter decay (Bellanca et al. 2005), which might be as a result of transportation of organic-rich material to the sandstones (Dutton 2008). The comparison of the stable isotope data sets from different parts of the world with the data of present study shows that the samples plot within relatively low temperature zone which also 
confirms thermal subsidence that is evidence in the basin between Albian and Cenomanian (Seokor 1994a, b; Brown et al. 1996).

The oldest sample in the TST was sourced from Barremian which is part of the first incursion of marine into the basin (Fig. 3) (SOEKOR 1994a, b; Brown et al. 1996). The oxygen isotope values fall within normal marine environment (Scholle 1978; Bellanca et al. 2005). Two of the samples, O_A1 (3,574 m) in LST of Barremian age and A_F1 $(1,178 \mathrm{~m})$ of TST in Turonian age fall within sea water range of -1.2 to $-0.7 \%$ VSMOW (Lavelle et al. 2001). K_A2 (1,963 m) sample in the TST indicate mixture of detrital grains (Garlick and Epstein 1967; Savin and Epstein 1970; Clayton et al. 1972; Eslinger et al. 1973; Blatt 1986; Graham et al. 1996). More than $90 \%$ of the samples in the basin show extremely light $\delta^{13} \mathrm{C}$ values (between -27 and $-20 \%$ ) of samples which could be a result of influence of terrestrial organic-rich material (Bellanca et al. 2005; Smith 1972). Approximately $10 \%$ of the samples analyzed in the setting shows moderately negative carbon isotope composition which may reflect normal marine signature slightly modified by variable contribution of $\mathrm{CO}_{2}$ derived from sedimentary organic matter decay (Table 2) (Bellanca et al. 2005).

The oxygen isotope data of samples from the HST show high ratio indicating a marine water precipitation in some Barremian age samples (Scholles 1978). Approximately $15 \%$ of the samples fall within sea water range of -1.2 and $-0.7 \%$ VSMOW (Lavelle et al. 2001). $15 \%$ of the samples also indicate mixture of detrital grains (Garlick and Epstein 1967; Savin and Epstein 1970; Clayton et al. 1972; Eslinger et al. 1973; Blatt 1986; Graham et al. 1996). The consistency of the $\delta^{13} \mathrm{C}$ values across the stratigraphic sequences with exception of well A_O1 in the LST and one sample in the TST is an indication that the burial diagenesis has not shown significant effect on the geochemical pattern of the $\delta^{13} \mathrm{C}$ (Schmid et al. 2006).
Diagenetic events within the depositional settings

The stable isotope results showed that the cementing materials were precipitated in temperate water and shallow marine conditions (Fig. 9). A marine environment is characterized by slightly alkaline waters (sea water $\mathrm{pH}$ is 8.3). The LST deposition occurs as a response to fall and slow rise in relative sea level (Worden and Morad 2003). The basin floor fan sediment of the LST setting must have bypassed the shelf through the incised valleys and deposited on the slope (Brown et al. 1996). Burial and mechanical compaction of the ductile interclast resulted in the formation of pseudomatrix as seen in the thin sections. During the early to middle Aptian extensive drowning of the margin occurred and regional organic-rich petroleum source shale was deposited (Van der Spuy 2003). The setting shows carbon isotope range of -25.667 to -7.820 (Table 2). The moderately negative carbon isotope values indicate a normal marine signature which may be slightly modified by a variable contribution of $\mathrm{CO}_{2}$ derived from sedimentary organic matter decay.

The authigenic calcite occurs in pores and fractures as micritic and coarsely crystalline or poikilitic calcite cements. Texturally, the calcite was formed after chlorite and quartz overgrowth, because the calcites are seen covering all these authigenic minerals in all the settings. Within the TST, micritic calcite cement was observed to continue to deeper depths (Fig. 6a, b). The original depositional textures are obscured in the sandstones across the stratigraphic settings of the Orange Basin, in which calcite cements occur as grain replacement. The poikilitic calcite cement in the HST samples in A_F1 was preserved and virtually outlines the grain contacts.

Chlorite precipitation implies basic pore solutions enriched in $\mathrm{Fe}^{2+}$ and $\mathrm{Mg}^{2+}$ (Small et al. 1992). A large volume of basic water source is sea water which is typically buffered between $\mathrm{pH} 8.0$ and 8.4 (Brownlow 1979). The results of pore water analysis of the samples across the
Fig. 9 Comparison of $\delta^{18} \mathrm{O}$ and $\delta^{13} \mathrm{C}$ values of the sandstone within the ages Barremian to Campanian in this study with published stable isotope data (in red text) from sandstones elsewhere in the world

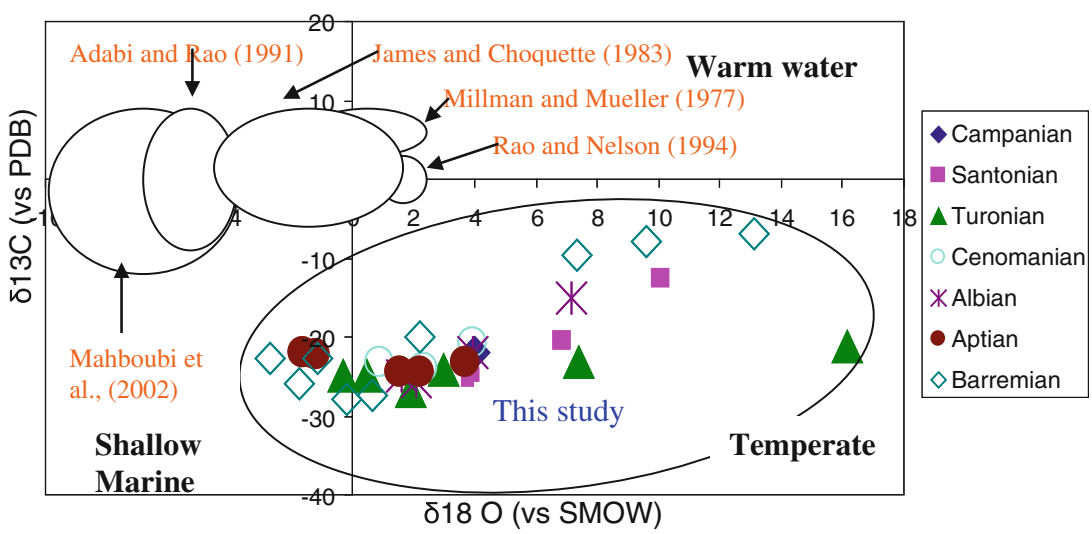


basin show a near similar condition. The LST shows average $\mathrm{pH}$ of 7.10, conductivity (Ec) average of $0.65 \mathrm{mS}$, and average redox potential (Eh) $0.16 \mathrm{~V}$ (Table 2). Within the TST the average $\mathrm{pH}$ is 7.32 , with Ec average of $0.56 \mathrm{mS}$ and Eh of $0.15 \mathrm{~V}$ (Table 2). The HST has an average $\mathrm{pH}$ of 7.52 , Ec of $0.72 \mathrm{mS}$ and average Eh of $0.74 \mathrm{~V}$ (Table 2). These conditions support clay conversion (De Ros et al. 1994). The $\mathrm{pH}$ values within the stratigraphic settings exceed 7 , thereby facilitating the reaction of $\mathrm{HCO}_{3}{ }^{-}$with dissolved $\mathrm{Ca}^{2+}$ to form calcite (Morse and Mackenzie 1990; Schulz and Zabel 2000). It is inferred that montmorillonite might have been converted to chlorite in the basin based on the XRD results and the dominance of chlorite over montmorillonite in the thin sections. The prevailing condition of the basin using chemical evaluation parameter discussed above satisfies Krumbein and Garrels (1952) explanations for determination of origin of these authigenic minerals. Pyrite found in the basin might have been formed from precipitation in alkaline condition. The silica precipitation requires weakly alkaline condition for its precipitation. The hematite that requires oxidizing condition for its precipitation can also persist in slightly reducing alkaline condition (Krumbein and Garrels 1952).

Diagenetic alteration within different stratigraphic settings shows both eodiagenetic and mesodiagenetic events (Fig. 8). Within the LST, eodiagenetic event includes montmorillonite precipitation. The micritc calcite and the pyrite trend span from eodiagenesis to mesodiagenesis. Chlorite, quartz overgrowth and hematite formation are mainly mesodiagenetic event in the LST. The TST shows limited eodiagenesis events only in pyrite and hematite formations. This may be as a result of coarse grained sediments entrapped landward thereby increasing the concentration of glauconite in Aptian sample A_C3 (3,675 m). This must have been the reason for the glauconite formation being pushed to the mesogenesis. The other mesodiagenetic events in the TST include chlorite, montmorillonite and quartz overgrowth formation. The main cementing materials in the settings are chlorite, micritic calcite and coarse crystalline calcite.

The HST shows more eodiagenetic events that span to mesodiagenesis with quartz overgrowth, hematite, pyrite and poikilitic calcite formations. The authigenic chlorite and montmorillonite are products of mesodiagenetic events. Deposition in the HST occurs in response to gradual sea level rise and later during initial stages of sea level fall. There was high influx of sediments in the Orange Basin during late Cretaceous (Brown et al. 1990; Dingle and Hendy 1984; Rust and Summerfield 1990); this may have caused shoreline transgression to give way for regression and also increasing progradational stacking (Worden and Morad 2003). This scenario may increase sand and mud ratio, the HST being accompanied by increase in the amount of authigenic glauconite, the reason for the eodiagenetic glauconite in HST in sample K_B1 $(1,350 \mathrm{~m})$ of Campanian age. Landward top of the HST is associated with widespread fluvial deposition (Posamentier et al. 1988). The fluvial deposit in well A_F1 within the HST may be formed as a result of prevailing temperate climatic conditions which are subjected to clay infiltration pedogenesis or the formation of Mg-rich clay minerals in the setting.

\section{Conclusions}

This study revealed a complex diagenetic history of sandstones of the Orange Basin in which compaction, cementation/micritization, dissolution, overgrowth of quartz and fracturing were observed. The cement precipitation occurs in different environments. The LST has micritic cement which is an evidence of marine diagenesis. The TST and HST have micritic and poikilitopic calcite cements that indicate different conditions of precipitation. The micritic morphology and coarse crystalline nature of the cementing materials strongly suggest autochthonous and allochthonous origin of the cementing materials, respectively. $50 \%$ of the LST samples show possibility of mixture between detrital quartz grains based on the oxygen isotope data. The detrital quartz mixture decreases from LST to TST and HST. The consistency of the carbon isotope values across the stratigraphic sequences indicates that burial diagenesis has no significant effect on the geochemical pattern of the sandstones but indicates contribution from land-derived materials into the basin.

The Eh-pH conditions in the basin show that the authigenic minerals were precipitated in slightly alkaline conditions; the TST is slightly more alkaline than HST, thereby causing more authigenic clay precipitation in the TST. The alkaline conditions also support clay conversion in the basin under a low relative temperature condition as a result of thermal subsidence in the basin between Aptian and Cenomanian, in which some of these samples were deposited.

The sandstones across the basin have pseudomatrix rich in authigenic chlorite, montmorillonite, quartz and calcite. These minerals cemented the pores thereby reducing porosity. The continued burial compaction disrupted the depositional texture which in turn impaired secondary porosity development leading to poor quality of the reservoir rocks.

Acknowledgments We appreciate Petroleum Agency South Africa (PASA) for releasing of the data set and samples for this study. Special thanks to Inkaba ye Africa for funding this study.

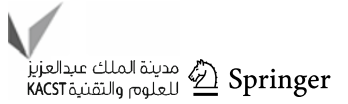


Open Access This article is distributed under the terms of the Creative Commons Attribution License which permits any use, distribution, and reproduction in any medium, provided the original author(s) and the source are credited.

\section{References}

Adabi MH, Rao CP (1991) Petrographic and geochemical evidence for original aragonite mineralogy of Upper Jurassic carbonate (Mozduran Formation), Sarakhs area, Iran. Sed Geol 72:253-267

Aizawa M, Bluck B, Cartwright J, Milner S, Swart R, Ward J (2000) Constraints on the geomorphological evolution of Namibia from the offshore stratigraphic record communications. Geol Surv Namibia 12:337-346

Allan JR, Wiggins WD (1993) Dolomite reservoirs: geochemical techniques and evaluating origin and distribution. AAPG Continuing Education Course Note Series 36, p 129

Bellanca A, Aghib F, Neri R, Sabatino N (2005) Bulk carbonate isotope stratigraphy from CRP-3 core (Victoria Land Basin, Antarctica): evidence for Eocene-Oligocene paleoclimatic evolution. Global Planet Change 4:237-247

Blatt H (1986) Oxygen isotopes and the origin of quartz. J Sed Petrol $57: 373-377$

Broad D (2004) South Africa activities and opportunities. An unpublished power point presentation to PetroChina

Broad DS, Jungslager EHA, Mclachlan IR, Roux J (2006) Offshore Mesozoic Basins. In: Johson MR, Anhaeusser CR, Thomas RJ (eds) Geological Society of South Africa. Council for Geoscience Pretoria, Johannesburg, pp 553-571

Brown RW, Rust DJ, Summerfield MA, Gleadow JW, De Wit MCJ (1990) An early cretaceous phase of accelerated erosion on the south-western margin of Africa: evidence from apatite fission track analysis and the offshore sedimentary record. Nucl Tracks Rad Meas 17:339-350

Brown LF, Brown LF Jr, Benson JM, Brink GJ, Doherty S, Jollands A, Jungslager EHA, Keenan JHG, Muntigh A, Van Wyk NJS (1996) Sequence stratigraphy in offshore South Africa divergent basins. An atlas on exploration for cretaceous lowstand traps by SQEKOR (Pty) Ltd. AAPG Stud Geol 41:184

Brownlow AH (1979) Geochemistry. Prentice-Hall, Englewood Cliffs, NJ

Clayton RN, Jr O’Neil, Mayeda TK (1972) Oxygen isotopic exchange between quartz and water. J Phy Res 77:3057-3067

De Ros LF (1998) Heterogenous generation and evolution of diagenetic quartz arenites in the Silurian-Devonian Furnas formation of the Panana Basin Southern Brazil. Sed Geol 11:99-128

De Ros LF, Sgarbi GNC, Morad S (1994) Multiple authigenesis of K-feldspar in sandstones: evidence from the Cretaceous Areado Formation, Sao Francisco Basin, central Brazil. J Sed Res A64:778-787

Dingle RV, Hendy QB (1984) Late Mesozoic and Tertiary sediment supply to the eastern Cape Basin (SE Atlantic) and palaeodrainage systems in southwestern Africa. Mar Geol 56:13-26

Dutton SP (2008) Calcite cement in Permian deep water sandstones, Delware Basin, West Texas. Origin, distribution and the effect of the reservoir properties. AAPG Bulletin 92:765-787

El-Ghali MAK, Morad S, Mansurbeg H, Caja MA, Sirat M, Ogle N (2009) Diagenetic alterations related to marine transgression and regression in fluvial and shallow marine sandstones of the Triassic Buntsandstein and Keuper sequence, the Paris Basin, France. Mar Petrol Geol 26:289-309
Emery KO, Uchupi E (1984) The geology of Atlantic Ocean. Springer, New York

Eslinger E, Mayer LM, Durst TL, Hower J, Savin SM (1973) An $\mathrm{X}$-ray technique for distinguishing between detrital and secondary quartz in the fine-grained fraction of sedimentary rocks. J Sed Petrol 43:540-543

Garlick GD, Epstein S (1967) Oxygen isotope ratios in coexisting minerals of regionally metamorphosed rocks. Geochim Cosmochim Acta 31:181-214

Garzanti E (1991) Non-carbonate intrabasinal grains in arenites: their recognition, significance, and relationship to eustatic cycles and tectonic setting. J Sed Petrol 61:959-975

Gerrard I, Smith GC (1982) Post-Palaeozoic succession and structure of southwestern African continental margin. In: Watkins JS, Drake CL (eds) Studies in continental margin geology. AAPG Memoir, vol 34, pp 49-76

Gilchrist AR, Kooi H, Beaumont C (1994) Post-Gondwana geometric evolution of southwestern Africa: Implications for the controls of landscape development for observations and numerical experiments. J Geophy Research 99(B6):211-228

Graham CM, Valley JW, Winter BL (1996) Ion microprobe analysis of $\mathrm{O}^{18} /{ }^{16} \mathrm{O}$ in authigenic and detrital quartz in the St. Peter Sandstone, Michigan Basin and Wisconsin Arch, USA: contrasting diagenetic histories. Geochim Cosmochim Acta 60:5101-5116

Hart BS, Longstaffe FJ, Plint AG (1992) Evidence for relative sealevel changes from isotopic and elemental composition of siderite in the Cardium Formation, Rocky Mountain Foothills. Bull Can Petrol Geol 40:52-59

Hirsch KK, Scheck-Wenderoth M, Van Wees JD, Kuhlmann G, Paton DA (2010) Tectonic subsidence history and thermal evolution of the Orange Basin. Mar Petrol Geol 27:565-584

James NP, Choquette PW (1983) Diagenesis 9. Limestones the seafloor diagenetic environment. Geosci Can 10:162-179

Ketzer JM, Morad S, Evans R, Al-Aasm IS (2002) Distribution of diagenetic alterations in fluvial, deltaic, and shallow marine sandstones within a sequence stratigraphic framework: Evidence from the Mullaghmore Formation (Carboniferous), NW Ireland. J Sed Res 72:760-774

King LC (1967) The morphology of the Earth, 2nd edn. Oliver \& Boyd, Edinburgh

King LC (1976) Planation remnants upon high lands. Zeitschrift für Geomorphologie NF 20:133-148

King LC (1983) Wandering continents and spreading sea floors on an expanding earth. Wiley, Chichester

Krumbein WC, Garrels RM (1952) Origin and classification of chemical sediments in terms of Eh and oxidation-reduction potentials. J Geol 60:1-33

Lavelle M, Fielding CR, Hall MA, Thomson MRA (2001) Molluscan stable isotope temperature estimates of the southwestern Ross Sea during early Oligocene and early Miocene, CRP-2/2A and CRP-3, Victoria Land Basin, Antarctica. Terra Antarct 8:439-444

Light MPR, Maslanyi MP, Greenwood RJ, Banks NL (1993) Seismic sequence stratigraphy and tectonics offshore Namibia. In: Williams G, Dobb A (eds) Tectonics and seismic sequence stratigraphy. Geological Society Special Publication, vol 71, pp 163-191

Macdonald D, Gomez-Perez I, Franzese J, Spalletti L, Lawver L, Gahangan L, Dalziel I, Thomas C, Trewin N, Hole M, Paton D (2003) Mesozoic break up of SW Gondwana: implications for regional hydrocarbon potential of southern South Atlantic. Mar Petrol Geol 20:287-308

Mahboubi A, Moussavi-Harami R, Brenner RL, Gonzalez LA (2002) Diagenetic history of Late Palaeocene potential carbonate reservoir rocks, Kopet-Dagh Basin, NE Iran. J Petrol Geol $25: 465-484$ 
Maslanyi MP, Light MPR, Greenwood RJ, Banks NL (1992) Extension tectonics offshore Namibia and evidence for passive rifting in the South Atlantic. Mar Petrol Geol 9:590-601

Mckay JL, Longstaffe FJ, Plint AG (1995) Early diagenesis and its relationship to depositional environment and relative sea-level fluctuations (Upper Cretaceous Marshybank Formation, Alberta and British Columbia). Sedimentology 42:161-190

McMillan IK (2003) Foraminiferally defined biostratigraphic episodes and sedimentary pattern of the Cretaceous drift succession (Early Barremian to Late Maastrichtian) in seven basins on the South African and southern Namibian continental margin. South African J Sci 99:537-576

Milliman JD, Muller J (1977) Characteristics and genesis of shallow water and deep-water limestone. In: Anderson NR, Malahoff A (eds) The fate of fossil fuel $\mathrm{CO}_{2}$ in the oceans. Plenum Press, New York, pp 655-672

Morad S, Ketzer JM, De Ros LF (2000) Spatial and temporal distribution of diagenetic alterations in siliciclastic rocks: implications for mass transfer in sedimentary basins. Sedimentology 47:95-120

Morse JW, Mackenzie FT (1990) Geochemistry of sedimentary carbonates. Developments in sedimentology, 48th edn. Elsevier, New York

Odin GS, Matter A (1981) De glauconiarum origine. Sedimentology, In: Banerjee S, Jeevankumar S, Eriksson PG. Mg-rich Ferric illite in marine trangressive and highstand system tracts: example for Paleoproterozoic Semri Group, central India. Precambrian Research 162:212-226

Parrish JT, Ziegler AM, Scotese CR (1982) rainfall patterns and the distribution of coals and evaporates in the Mesozoic and Cenozoic. Paleogeogr Palaeclimatol Palaeoecol 40:67-101

PASA (2003) Southern Orange Basin Exploration opportunities offshore South Africa's West Coast. Petroleum Agency of South Africa. www.petroleumagencysa.com

Posamentier HW, Jervey MT, Vail PR (1988) Eustatic controls on clastic deposition I- conceptual framework. In: Wilgus CK, Hastings BS, Posamentier H, Van Wagone J, Ross CA, CGStC Kendall (eds). Sea level changes: an integrated approach. Society for sedimentary Geology Special Publication 42:109-124

Rao CP, Nelson CS (1992) Oxygen and carbon isotope field for temperature shelf carbonates from Tasmania and New Zealand. Mar Geol 103:273-286

Reeves C, De Wit M (2000) Making ends meet in Gondwana: retracing the transforms of the Indian Ocean and reconnecting continental shear zones. Terra Nova 12:272-280

Rust DJ, Summerfield MA (1990) Isopach and borehole data as indicator of rifted margin evolution in southwestern Africa. Mar Petrol Geol 7:277-287
Savin SM, Epstein S (1970) The oxygen isotopic compositions if coarse grained sedimentary rocks and minerals. Geochim Cosmochim Acta 34:323-329

Schmid S, Worden RH, Fisher QJ (2006) Carbon isotope stratigraphy using carbonates in the Triassic Sherwood Sandstone: Corribed field. West of Ireland. Chem Geol 225:137-155

Scholle PA (1978) A colour illustrated guide to carbonate rocks constituents, textures, cement and porosity. AAPG Memoir 27:129-168

Schulz HD, Zabel M (2000) Marine geochemistry. Velarg, Berlin

Shikazono N, Utada M (1997) Stable isotope geochemistry and diagenetic mineralization associated with Tono sandstone-type uranium deposit in Japan. Miner Deposita 32:596-606

Siesser WG, Dingle RV (1981) Tertiary sea-level movements around southern Africa. South African J Geol 89:83-96

Small JS, Hamilton DL, Habesch S (1992) Experimental simulation of clay precipitation within reservoir sandstones, 1 . Techniques and examples. J Sed Petrol 62:520-529

Smith BN (1972) Natural abundance of the stable isotopes of carbon in biological systems. Biosciences 22:226-231

SOEKOR (1994a) Orange Basin. Report of South Africa licensing round information brochure, $\mathrm{p} 18$

SOEKOR (1994b) Outeniqua Basin. Report of South Africa licensing round information brochure, $\mathrm{p} 52$

Taylor KG, Gawthorpe RL, Van Wagoner JC (1995) Stratigraphic control on laterally persistent cementation, Book Cliff, Utah. J Sed Res 69:225-228

Tyson PD (1986) Climatic change and variability in Southern Africa. Oxford University Press, New York

Van Der Spuy D (2003) Aptian source rocks in some South African Cretaceous basin. Geol Soc Lond Special Publ 207:185-202

Van Wagoner JC, Mitchum RM, Campion KM, Rahmanian VD (1990) Siliciclastic sequence stratigraphy in well logs, cores, and outcrops. AAPG Methods Explor 7:55

Ward JD, Seely MK, Lancaster N (1983) On the antiquity of the Namabia. South Africa J Sci 79:175-183

Wilkinson M (1989) Discussion: evidence for surface reaction controlled growth of carbonate concretions in shales. Sedimentology 36:951-953

Worden RH, Morad S (2003) Clay mineralisation in sandstone: controls on formation, distribution and evolution. In: Worden RH, Morad S (eds) Clay mineral cements in sandstones. International Association of Sedimentologists. Wiley, NY, pp 3-42

Zuffa GG, Cibin U, Di Giulio A (1995) Arenite petrography in sequence stratigraphy. J Geol 103:451-459 